析值 $10.93 \% ， \mathrm{~N}$ 計算值 $11.01 \%$ ） $3.7 \mathrm{~g}$ をうる。このものは標 品と混融して融点降下をしめさない。さらに先に分雒した油状物 をピクリン酸エタノール溶液で処理したところ, $p, p^{\prime}$ ービス (ジメ チルアミノ）ジフェニルメタンピクラート $\left(\mathrm{mp} 185^{\circ} \mathrm{C}\right)$ が多量

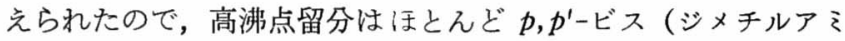
ノ）ジフェルメタンであることがわかった。このことはまたつ ぎの方法で酸化することによってもたしかめられた。

$2.2 \boldsymbol{p}, \boldsymbol{p}$-ビス (ジメチルアミノ) ベンズヒドロール（ミヒラ 一ヒドロール): 硝酸鉛 $16.5 \mathrm{~g}$ を $500 \mathrm{ml}$ の水にとかした溶液に クロルカルキ飽和水溶液を沈殿がもはや生じなくなるまで加え, 生成した褐色沈殿を水洗後 $500 \mathrm{ml}$ の水に分散させて二酸化鉛懸 濁液をつくっておく。

2.1 の方法でえた高沸点留分 $13 \mathrm{~g}$ を裖增酸 $10 \mathrm{ml}$, 水 $20 \mathrm{ml}$ の混液に加熱溶解させたのち氷酢酸 $6 \mathrm{~g}$ を加え氷水 $2 \mathrm{~kg}$ と混合 する。これに二酸化鉛懸濁液を加え 5 分間かきまぜたのち，無水 硫酸ナ、リウム $7.1 \mathrm{~g}$ を $100 \mathrm{ml}$ の水にとかした溶液を加えて
30 分間かきまぜる。生成した硫酸鉛をロ別し，青紫色の口液を $5 \%$ 水酸化ナトリウムで中和し, 析出する沈殿を口取水洗乾燥後 エーテルから再結晶すれば， こヒラーヒドロール $\left(\mathrm{mp} 94^{\circ} \mathrm{C}\right) 10$ g（収率 $72 \%$ )をうる。

$2.3 \beta$-ジメチルアミノプロピオフェノン塩酸塩とジメチルア ニリンとの反応: ジメチルアそノプロピオフェノン塩酸塭》 $11 \mathrm{~g}$ とジチルアニリン $120 \mathrm{~g}$ とを 2.1 と同様にして 40 時間加熱 反応させる。反応混合物を分留して留出温度 $85^{\circ} \mathrm{C} / 11 \mathrm{mmHg}$ 以 下の低沸点留分 $75 \mathrm{~g}$ ，および $200^{\circ} \sim 220^{\circ} \mathrm{C} / 5 \mathrm{mmHg}$ の高沸点 留分 $8.3 \mathrm{~g}$ をうる。 2.1 と同様に操作して, 低沸点留分からはア セトフェノン-2,4-ジニトロフェニルヒドラゾン $\left(\mathrm{mp} 237^{\circ} \mathrm{C}\right) 1.1$ $\mathrm{g}$ をえ, 高沸点留分から $p, p^{\prime}$ ービス（ジメチルアミノ）ジフェニ ルメタン $\left(\mathrm{mp} 90^{\circ} \mathrm{C}\right) 2.5 \mathrm{~g}$ をえた。

(1959 年 4 月, 日本化学会第 12 年会講演)

7) C. E. Maxwell, “Org. Syntheses" Coll. Vol. 3, p. 305 (1955), John Wiley and Sons, Inc., New York, N. Y.

\title{
2, 5-ジオキシーp-ベンゾキノン銅（II）錯体のコロイド粒子の形状と性質
}

（昭 和 35 年 1 月 20 日受理）

神 田 精 一十

\section{1 緒 言}

2,5-ジオキシーpーベンゾキノン銅（II)錯体（A）は前に発表し たとおり銅イオンを有機配位子で連稀た高分子量の錯体であると 推定される1。通常の分子量測定法や構造決定法を適用すること は困難であるが，希薄なコロイド溶液が得られるのでとの粒子の 形状を測定した。その他に光学的異方性や螢光性も認めた。

\section{2 実 験}

2.1 試 料: 2,5-ジオキシ-p-ベンゾキノンのアルコール 溶液 と, 当量の酢酸銅アルコール溶液とを混合し, 生成するゲル状沈 殿を水で洗い, 多量の蒸留水と強く振る。その上澄液を測定の前 にグラスフィルターNo.5 でロ過して使う。濃度は約 $10^{-2} \mathrm{~g} / l$ である( $\mathrm{a}$ 液)。

2.2 電子顕微鏡： 㲘濁法で 2 万倍の像を得た。長さ 2000 $5000 \AA$ の棒状粒子がみとめられる。幅はほとんどが $500 \AA$ 以下 である。液中に分散している状態では長さ幅ともにこれ以下のも のと考えられる（図 1 参照）。

2.3 光散乱：上記 $\mathrm{a}$ 液とその $1 / 2$ 浱度にうすめたものについ て非対称係数 $q_{\theta}$ を測り, 濃度 0 に外挿した。 $\lim _{c \rightarrow 0} q_{\theta}=0.58$ (装 置: Brice 型光散乱光度計), Doty の図 22から粒子の大きさが求 まる。多分散性を無視し棒状剛体として長さの平均值 $1800 \AA$ を 得た (図 2 参照)。

2.4 流動複屈折： $\mathrm{a}$ 液について 外部円筒回転式装置で 複屈折 度 $\Delta n$, 消光角 $\chi$ を速度勾配 $g$ が 150 から $4350 \mathrm{sec}^{-1}$ の範囲で 測った。 $\Delta n \sim g \eta(\eta=1.4$ センチポイズ）曲線から粒子は剛体で

$\dagger$ 大阪市立大学理学部, 大阪市北区南扇町

1) S. Kanda, Y. Saito, Bull. Chem. Soc. Japan 30, 192 (1957).

2) 日本化学会編, “実験化学㩐座” 8, 「高分子化学」(上), p. 98 (1955) 丸 善.

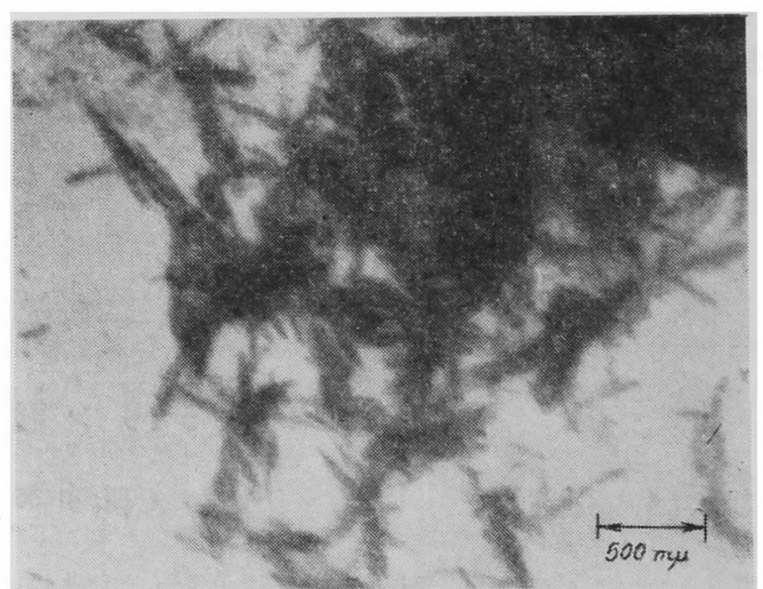

図 1 コロイド粒子の電子顕微鏡写真

あろうと推定される。 $\chi \sim g \eta$ 曲線から粒子の大きさを求め るため, まず一定の長さの剛 体棒状粒子を仮定し, 式*1 お よ゙び Scheragaの表3によっ て各種の長さと軸比について $\chi \sim g \eta$ の理論曲線群を求め る。それらの曲線と実験曲線 を比較したが $g \eta の$ 全測定範

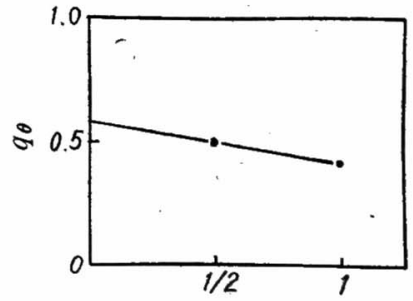

相対濃度

図 2 光 散 乱 囲にわたり一致する 1 本の曲線はなかった（図 3 次頁，参照）。

*1 式, 粒子の長さ $l=2 a=404(-1+2 \ln 2 a / b) \times(\alpha T / g \eta)^{1 / 3}$

3）日本化学会編, “実験化学輩座”8,「高分子化学」(上), p. 264 (1955) 丸 善. 


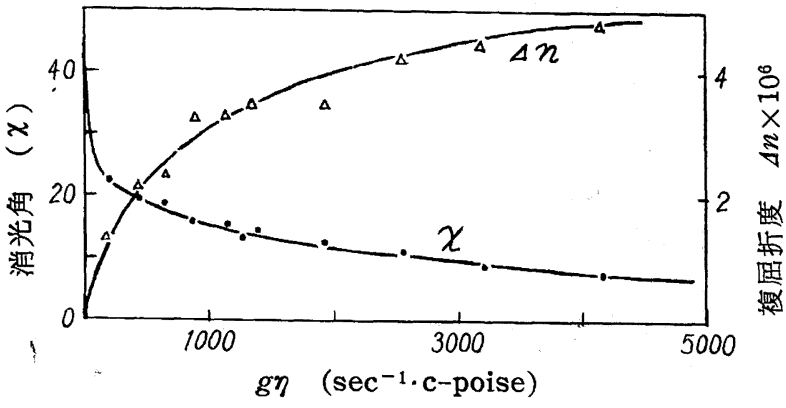

図 3 消光角と複届折度

それは液が静止かまたはそれに近 い状態 $(g \eta<500 * 2)$ では粒子同 志がいくぶんからみ合っており， はげしく流動しているとき（ $g \eta>$ 1000）は，それらが離れて長さ 1000 1500 の の剛体棒状粒子と して個々に配向すると考えると 実験值を説明することができる。 $g \eta<500$ の場合に形式的に長さを 計算すると 1500 ～ $1900 \AA$ となる。 剛体盤状体であると仮定して実 験值から計算すると直径 7500〜 $10000 \AA$ の粒子が存在しなくては ならないことになり，他の測定結 果から見ても明らかに，盤状粒子

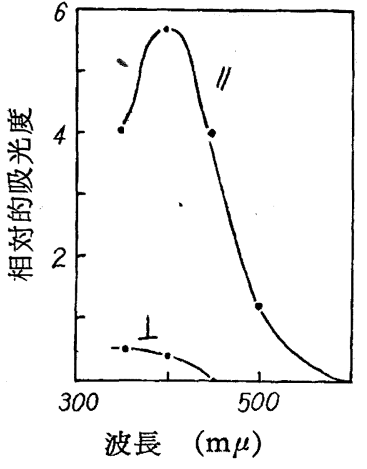

$\|, \perp$ は光の電気ベクト ルと P V A 膜の引伸方向 との関係

図 422 色 性 の仮定は不適当である。

2.52 色性: A物質のコロイド粒子を PVA 膜中に分散させ， それを一方向に引伸し，Beckman DU 型光電光度計のセル部

*2 $g \eta$ の単位: $g$ は $\mathrm{sec}^{-1}, \eta$ はセンチポイズすなわちポイズ $(\mathrm{g} / \mathrm{cm} \cdot \mathrm{sec})$ の $1 / 100$ で表わす. 以下同じ.
分におき，検光子を用いて相対的吸光度を測った。図 4 に示すよ うに波長 $400 \mathrm{~m} \mu$ 付近における吸収にはなはだしい異方性がみと められる。棒状粒子が P V A 膜を引伸した方向に配向し，その方 向に電気ベクトルのある光がとくに強く吸収されるものと思われ る。

2.6 螢光性: このコロイド溶液は太陽光線の照射により, 肉眼 でタとめうる強い螢光を発する。さらに他の研究者達の私信によ れば $\gamma$ 線に対しても水溶液*3 およびポリスチレン*4 中に分散させ た系で䖝光現象がみとめられる。

\section{3 結 論}

1) 粒子は 剛体棒状である。2）長さ注静止液中で主として 1500～2000 の の間に分布している。 3 ） はげしく流動している

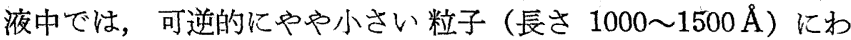
かれる傾向がある。これは 2 ) の状態では粒子がいくぶん会合し ているためであるうと思われる。4 ) 濃度がうすいため幅をきめ るための実験が不可能であったので粒子の幅については確かなこ とはわからない。5）A物質の分子構造は二次元網状構造より直 鎖状高分子構造がより可能性が大きいと推定される（粒子がかな り小さいので，分子が高分子であることも考え合わせると，高分 子の会合体であると考えられる粒子の形と個々の分子の形の間に かなりの相似的関係があるものと仮定しての推論である)。

電子顕微鏡で大阪大学生物学科, 専売公社中央研究所, 松下電 工K K, 光散乱では大阪大学尾山外茂男氏，流動複屈折では名古 屋大学大沢文夫助教授，今井宣久氏に御援助を戴いた。また大阪 市立大学斎藤喜彦, 川口信一雨教授はじめ多くの方々に御指導を 戴いた。てれらの方々に深く感謝する。

（1956 年 10 月，錯塩化学討論会，1958 年 4 月，日本化学会 第 11 年会講演)

*3 大阪大学物理, 平尾.

$*_{4}$ 原子核研究所, 三浦.

\section{エピコレステリン誘導体の次亜塩素酸付加反応}

(昭 和 35 年 1 月 26 日受理)

$$
\text { 武川文 一十 }
$$

\section{1 緒 言}

前報1に引きつゔき， $\mathrm{C}_{(3)}$-置換基が $\Delta^{5}$-ステロイドの次亜塩素 酸付加反応（塩化イソシアヌルー酢酸）におよぼす影響を知る目 的で表題の実験を行なったので，得られた結果を報告する。

\section{2 実験結果とその考察}

$3 \alpha$-ベンゾイルオキシーコレスト-5-エン（I）を酢酸を含むアセ トン中で塩化イソシアヌル(ICC)を作用させると $\mathrm{C}_{34} \mathrm{H}_{51} \mathrm{O}_{3} \mathrm{Cl}$ (II) $\mathrm{mp} 87^{\circ} \mathrm{C}$ が得られる。II はエタノール中で覀鉛末と煮沸すると ふたたびもとのI䘮，エタノール中で水酸化カリウムと煮沸する と $5,6 \beta$-オキシド- $5 \beta$-コレスタン $-3 \alpha$-オール(II) を与える。II の赤外線吸収スペクトルは, 固体 $(\mathrm{Nujiol})$ では $3418 \mathrm{~cm}^{-1}(\mathrm{OH})$,

$†$ 倠見化学研究所，㮖浜市鹤見区下野谷町

1) 武川, 日化 78, 452 (1957).
$1711 \mathrm{~cm}^{-1}(\mathrm{C}=\mathrm{O}), 1207 \mathrm{~cm}^{-1}(\mathrm{C}-\mathrm{O}-), 711 \mathrm{~cm}^{-1}$ (《), $685 \mathrm{~cm}\left(\mathrm{C}_{(5)}-\mathrm{Cl}(\text { axial })\right)^{2)}$ に吸収が認められた。また四塩化炭 素溶液でフッ化リチウムのプリズムを用いて水酸基の吸収を詳細

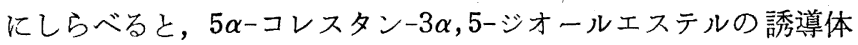
など3)4)に認められたような強い分子内水素結合にもとゔく吸収 は認められず, $3 \beta$-ベンゾイルオキシ-5-クロル-5 $\alpha$-コレスタン$6 \beta$-オールと類似した水酸基の吸収 $\left(3630 \mathrm{~cm}^{-1}\right.$ (強), $3587 \mathrm{~cm}^{-1}$ (局)）を示した。さてこのように $\beta$-オキシドを与える事実や，

2) D. H. R. Barton, J. E. Page, C. W. Shoppee, J. Chem. Soc. 1956, 331. $C_{(6)}$-クロル原子 (axial) は $706 \mathrm{~cm}^{-1}$ と報告されている.

3) H. B. Henbest, B. J. Lovell, J. Chem. Soc. 1957, 1965; H. B. Henbest, G. D. Meakins, J. I. Wrigley, ibid. 1958, 2633.

4) 武川, 日化第13年会䍀演 (1960). 